\title{
Inflammatory Cell Recruitment in Cardiovascular Disease
}

\author{
Timoteo Marchini ${ }^{1,2,3}$, Lucía Sol Mitre ${ }^{1,2}$ and Dennis Wolf $f^{1,2 *}$ \\ ${ }^{1}$ Department of Cardiology and Angiology I, University Heart Center Freiburg, Freiburg, Germany, ${ }^{2}$ Faculty of Medicine, \\ University of Freiburg, Freiburg, Germany, ${ }^{3}$ Facultad de Farmacia y Bioquímica, Instituto de Bioquímica y Medicina \\ Molecular (IBIMOL), Universidad de Buenos Aires, CONICET, Buenos Aires, Argentina
}

OPEN ACCESS

Edited by:

Zhichao Fan,

UCONN Health, United States

Reviewed by:

Gabriel Courties,

Médecine Régénératrice Et Immunothérapies, France

Yvonne Döring,

Ludwig Maximilian University

of Munich, Germany

${ }^{*}$ Correspondence:

Dennis Wolf

dennis.wolf@universitaets-

herzzentrum.de

Specialty section:

This article was submitted to

Cell Adhesion and Migration,

a section of the journal

Frontiers in Cell and Developmental

Biology

Received: 30 November 2020

Accepted: 21 January 2021

Published: 18 February 2021

Citation:

Marchini T, Mitre LS and Wolf $D$ (2021) Inflammatory Cell Recruitment

in Cardiovascular Disease.

Front. Cell Dev. Biol. 9:635527.

doi: 10.3389/fcell.2021.635527
Atherosclerosis, the main underlying pathology for myocardial infarction and stroke, is a chronic inflammatory disease of middle-sized to large arteries that is initiated and maintained by leukocytes infiltrating into the subendothelial space. It is now clear that the accumulation of pro-inflammatory leukocytes drives progression of atherosclerosis, its clinical complications, and directly modulates tissue-healing in the infarcted heart after myocardial infarction. This inflammatory response is orchestrated by multiple soluble mediators that enhance inflammation systemically and locally, as well as by a multitude of partially tissue-specific molecules that regulate homing, adhesion, and transmigration of leukocytes. While numerous experimental studies in the mouse have refined our understanding of leukocyte accumulation from a conceptual perspective, only a few anti-leukocyte therapies have been directly validated in humans. Lack of tissuetropism of targeted factors required for leukocyte accumulation and unspecific inhibition strategies remain the major challenges to ultimately translate therapies that modulate leukocytes accumulation into clinical practice. Here, we carefully describe receptor and ligand pairs that guide leukocyte accumulation into the atherosclerotic plaque and the infarcted myocardium, and comment on potential future medical therapies.

Keywords: atherosclerosis, myocardial infarction, recruitment, leukocyte, selectin, integrin, cytokine, chemokine

\section{INFLAMMATORY LEUKOCYTE RECRUITMENT PROMOTES CARDIOVASCULAR DISEASE}

Cardiovascular disease (CVD) represents the leading cause of mortality worldwide (Braunwald, 2012) and is mostly caused by atherosclerosis, a chronic inflammatory disease of middle- to large-sized arteries that is characterized by vessel-obstructing atherosclerotic plaques in the subendothelial space (Ross, 1999). The spontaneous rupture of atherosclerotic plaques, the subsequent formation of occlusive arterial thrombi, and the restriction of blood flow precipitates myocardial infarction (MI) and stroke (Minicucci et al., 2011). Initial atherosclerotic lesions develop in arteries with enhanced shear stress, turbulent blood flow, and endothelial dysfunction (Davignon and Ganz, 2004). This process is stimulated by traditional cardiovascular risk factors, such as smoking, hypertension, obesity, diabetes, and environmental stressors (Marchini et al., 2020). In atherosclerotic arteries, plasma low-density lipoproteins (LDL) are deposited in the subendothelial space and modified by oxidative processes. While oxidized LDL (oxLDL) exerts an inflammatory response of stromal cells itself, its uptake by tissue-resident macrophages initiates a myeloid-cell dominated pro-inflammatory cellular immune response (Swirski et al., 2007). It is now clear that inflammation is one of the key drivers of atherosclerosis, adverse cardiac remodeling, and myocardial scar formation after MI (Epelman et al., 2015). This response is characterized by the continuous accumulation of myeloid cells and lymphocytes in the atherosclerotic plaque, the 
myocardium, and draining lymph nodes of the heart (Epelman et al., 2015; Winkels et al., 2018; Farbehi et al., 2019; Wolf and Ley, 2019; Zernecke et al., 2020). Infiltrated leukocytes interact with stromal cells, secrete pro- or anti-inflammatory cytokines, and curb or promote inflammation and adverse tissue remodeling (Koltsova et al., 2012; Wolf et al., 2015; Sharma et al., 2020). While heart and vascular tissue contains small fractions of tissueresident leukocytes that partially stem from embryonic origin (Wolf et al., 2015; Ensan et al., 2016), the recruitment and accumulation of blood-derived leukocytes represents a central and ongoing process that correlates with disease severity and clinical outcomes (Galkina et al., 2006; Swirski et al., 2006; Leistner et al., 2020). In addition, tissue inflammation promotes the local proliferation of macrophages and other leukocytes, although the relative contribution of in situ proliferation to the overall content of tissue leukocytes remains a matter of debate. While anti-leukocyte therapies are already in clinical use against Inflammatory Bowel Disease (IBD) and Multiple Sclerosis (Ley et al., 2016), it remains unknown whether similar strategies would be effective in cardiovascular pathologies. Here, we evaluate factors that promote leukocyte accumulation into the atherosclerotic plaque and cardiac tissue in mice and discuss their potential as targets for future medical therapies in CVD.

\section{CURRENT CONCEPT OF VASCULAR LEUKOCYTE TRAFFICKING}

The stepwise cascade of leukocyte recruitment comprises leukocyte rolling, chemokine-driven cell activation, integrindependent cellular arrest, and transmigration. This sequence of events has lately been refined by additional (and intermediate) states, such as slow rolling, adhesion strengthening, intraluminal crawling, paracellular and transcellular migration, and migration through the endothelial basement membrane (Ley et al., 2007). These processes in the leukocyte can be attributed to distinct classes and pairs of adhesion receptors and ligands: Initial rolling is mediated by the interaction of C-type lectins with glycoprotein ligands: E-Selectin on endothelial cells with leukocyte E-Selectin Ligand 1 (ESL-1) (Levinovitz et al., 1993) and endothelial P-Selectin and leukocyte L-Selectin with P-Selectin Glycoprotein Ligand 1 (PSGL-1) (McEver and Cummings, 1997). PSGL-1 is expressed on both, leukocytes (An et al., 2008) and endothelial cells (da Costa Martins et al., 2007). Integrins, $\alpha / \beta$-heterodimers of a heterogeneous groups of $18 \alpha$ - and $8 \beta$-subunits (Takada et al., 2007), participate in (slow) rolling and mediate cell firm adhesion (Dunne et al., 2003). Of the 24 integrins, $\alpha_{L} \beta_{2}$, $\alpha_{M} \beta_{2}, \alpha_{x} \beta_{2}, \alpha_{d} \beta_{2}, \alpha_{4} \beta_{7}$ and $\alpha_{E} \beta_{7}$ are selectively expressed on leukocytes while $\alpha_{2} \beta_{1}, \alpha_{3} \beta_{1}, \alpha_{5} \beta_{1}, \alpha_{6} \beta_{1}, \alpha_{6} \beta_{4}, \alpha_{10} \beta_{1}, \alpha_{v} \beta_{3}$ and $\alpha_{\mathrm{v}} \beta_{5}$ are expressed on ECs (Finney et al., 2017). Integrindependent leukocyte arrest is best established for the interaction of Very Late Antigen 4 (VLA-4, $\left.\alpha_{4} \beta_{1}\right)$ with Vascular Cell Adhesion Protein 1 (VCAM-1) (Berlin et al., 1995; Ley and Huo, 2001), of Lymphocyte Function-associated Antigen 1 (LFA-1, CD11a/CD18, $\alpha_{\mathrm{L}} \beta_{2}$ ) with Intercellular Adhesion Molecule 1 (ICAM-1) (Meerschaert and Furie, 1995), and of Macrophage Receptor 1 (Mac-1, CD11b/CD18, $\alpha_{M} \beta_{2}$ ) with EC-expressed
ICAM-1 (Dunne et al., 2003) and CD40 ligand (CD40L) (Wolf et al., 2011, 2018; Michel et al., 2017). Firm adhesion is topically guided by the $\mathrm{C}-\mathrm{C}$ motif chemokines CCL2 (Monocyte Chemoattractant Protein 1, MCP-1) and CCL5, and by the C-X-C motif chemokines CXCL1, CXCL4, and CXCL5 (Noels et al., 2019), which are secreted by cells in the atherosclerotic lesion or deposited by activated platelets (Drechsler et al., 2010) and subsequently presented on the glycocalyx (Graham et al., 2019). Binding of chemokines to their corresponding chemokine receptors on leukocytes, such as CCR2 (binding CCL2) or CCR5 (binding CCL3, -4 , and -5 ), is critical for adhesion strengthening (Zernecke and Weber, 2014) and partially requires sialylation of CCRs by leukocyte-expressed $\alpha 2,3$-sialyltransferase IV (St3Gal4) as exemplified by CCR5 (Doring et al., 2014). Chemokine binding results in activationdependent conformational changes in integrins (inside-out signaling) that induces an extended intermediate- and highaffinity structure of integrins (Arnaout et al., 2005; Fan and Ley, 2015; Fan et al., 2016) with a 10,000 -fold increased affinity for their ligands (Shimaoka et al., 2003). Leukocyte migration is further supported by proinflammatory cytokines, such as IL-1 $\beta$, that induce an upregulation of ICAMs, Platelet/Endothelial Cell Adhesion Molecule 1 (PECAM-1) (Mamdouh et al., 2003), and Junctional Adhesion Molecule A (JAM-A) (Martin-Padura et al., 1998). Transendothelial cell migration requires leukocyte integrins, in particular Mac-1 (Ley et al., 2007). While this cascade ultimately results in the accumulation of most leukocytes, a sub-population of Ly6 $\mathrm{C}^{\text {low }}$ monocytes remains crawling on the endothelium for surveillance of endothelial integrity engaging LFA-1, C- $\mathrm{X}_{3}-\mathrm{C}$ Chemokine Receptor 1 ( $\left.\mathrm{CX}_{3} \mathrm{CR} 1\right)$ (Auffray et al., 2007), and ICAM-1 and ICAM-2 (Ancuta et al., 2009). Whether these patrolling monocytes eventually transmigrate and contribute to the pool of tissue leukocytes remains a matter of debate (Auffray et al., 2007; Nahrendorf et al., 2007; Heidt et al., 2014a; Hilgendorf et al., 2014; Quintar et al., 2017).

The (numeric) regulation of leukocyte recruitment occurs via several mechanisms: First, leukocytes are activated by cytokines such as Tumor Necrosis Factor (TNF)- $\alpha$ or by oxLDL that promote expression of selectins (Stocker et al., 2000) and integrins (Couffinhal et al., 1994; Kita et al., 2001). Second, leukocyte activation may occur via an interaction with other cells, such as platelets that secrete leukocyte-activating factors as serotonin (Mauler et al., 2019). Third, the endothelium upregulates expression of adhesion receptors during systemic and local inflammation. Fourth, the pool of available leukocytes in the circulation is regulated by an enhanced production in the bone marrow or at sites of extramedullary hematopoiesis (EMH), such as the spleen (Swirski et al., 2009; Dutta et al., 2012; Heidt et al., 2014b). Under steady-state conditions, haematopoietic stem cell (HSC) homeostasis is regulated by bone marrow endothelial cell expressed CXCL12 (Stromal Cell-Derived Factor 1, SDF-1) that serves as retention and quiescence factor for HSCs and progenitor cells in the bone marrow niche that express its receptor CXCR4 (Mendez-Ferrer et al., 2008, 2010; Wolf and Ley, 2015; Krohn-Grimberghe et al., 2020). In the setting of inflammation, an enhanced sympathetic tone reduces CXCL12 expression in the bone marrow and increases CCL2 in bone 
marrow sinusoids that guides newly generated monocytes into the circulation (Krohn-Grimberghe et al., 2020). The migration factors required for seeding HSCs and progenitor cells to the sites of EMH are currently unknown. Fifth, tissue and cell tropism is regulated by a site-specific expression of adhesion factors: For instance, lymphocyte trafficking in the gut is predominantly facilitated by leukocyte $\alpha_{4} \beta_{7}$ and $\alpha_{\mathrm{E}} \beta_{7}$ and endothelial Mucosal Addressin Cell Adhesion Molecule 1 (MAdCAM-1) (Briskin et al., 1993) and E-Cadherin (Higgins et al., 1998). In a secondary analysis of vascular adhesion receptors from the endothelial database EndoDB (Khan et al., 2019), we found a predominant expression of P- (SELP) and E-Selectin (SELE), integrin subunits $\alpha_{3}$ (ITGA3), $\alpha_{5}$ (ITGA5), $\alpha_{9}$ (ITGA9), $\alpha_{10}$ (ITGA10), $\beta_{1}$ (ITGB1) and $\beta_{3}$ (ITGB3), and VCAM-1 (VCAM1) and ICAM-1 (ICAM1) in endothelial cells from human coronary arteries and the aorta compared to other vascular beds, suggesting these may figure as potent mediators of cardiac leukocyte accumulation during inflammation (Figure 1).

\section{INFLAMMATORY LEUKOCYTE RECRUITMENT IN ATHEROSCLEROSIS}

A multitude of established receptor-ligand pairs has been validated mostly in experimental atherosclerosis in mice deficient for LDL-receptor $\left(\mathrm{Ldlr}^{-/-}\right)$and Apolipoprotein E $\left(A p o e^{-/-}\right)$, which exhibit diet-induced hypercholesterolemia (Wolf et al., 2015). Important recruitment factors include selectins, integrins, and other classes of adhesion factors (Galkina and Ley, 2007b) that can act in different cell types (Galkina and Ley, 2007a; Soehnlein, 2012; Gerhardt and Ley, 2015; Saigusa et al., 2020; Figure 2A):

\section{Cardiac Endothelial Cells}

Endothelial cell expressed selectins (CD62) interact with glycoprotein ligands to mediate the capture and slow-down of circulating leukocytes. In humans, P-Selectin is not detectable in the healthy arterial endothelium but it is upregulated by oxLDL (Gebuhrer et al., 1995) and highly expressed in atherosclerotic lesions (Johnson-Tidey et al., 1994). Likewise, E-Selectin is detectable on the endothelium of human atherosclerotic plaques (Davies et al., 1993). While P-Selectin deficiency $\left(\mathrm{Psel}^{-/-}\right.$) in Apoe $\mathrm{I}^{-/}$and $\mathrm{Ldlr}^{-/-}$mice (Johnson et al., 1997;
Dong et al., 2000) neutralizes leukocyte trafficking and delays disease progression (Mayadas et al., 1993), Apoe ${ }^{-/-} \mathrm{Esel}^{-/-}$mice are less affected (Collins et al., 2000). A combined deficiency of P- and E-Selectin in $\mathrm{Ldlr}^{-/-}$mice abolishes atherosclerosis (Dong et al., 1998). P-Selectin, but not E-Selectin, expression correlates with human plaque stability (Tenaglia et al., 1997). Deficiency of VCAM-1 (Cybulsky et al., 2001) and ICAM-1 (Nageh et al., 1997) diminishes plaque size in mice. VCAM-1 is upregulated by proinflammatory cytokines at atherosclerosisprone sites of arteries in $A p o e^{-/-}$and WT mice and mediates leukocyte arrest by binding to VLA-4 (Nakashima et al., 1998; Ley and Huo, 2001; Jongstra-Bilen et al., 2006). Leukocyte adhesion on the endothelium is also supported by binding of ICAMs to LFA-1 (Meerschaert and Furie, 1995) and of CD40L to Mac-1 (Zirlik et al., 2007). Small interfering RNAs (siRNAs) targeting multiple endothelial adhesion molecules reduced atherosclerosis in $A p o e^{-/-}$mice markedly (Sager et al., 2016a), while specific targeting of Mac-1 binding to CD40L by a peptide inhibitor (Wolf et al., 2011), or a blocking antibody (Wolf et al., 2018) prevented inflammatory leukocyte recruitment (Michel et al., 2017) in mice.

\section{Monocytes}

In $A p o e^{-/-}$and $L d l r^{-/-}$mice, hypercholesterolemia results in an expansion of monocyte progenitors and systemic monocytosis (Soehnlein et al., 2013; Rahman et al., 2017), likely by a modulation of reverse cholesterol transport in Hematopoietic Stem Progenitor Cells (HSPCs) (YvanCharvet et al., 2010; Murphy et al., 2011) and accelerated extramedullary hematopoiesis (Robbins et al., 2012). Several reports have identified increased adrenergic signaling, impaired quiescence and retention of HSPCs as hallmarks of this response (Dutta et al., 2012; Courties et al., 2015; Sager et al., 2016b). In the plaque, classical/inflammatory Ly-6C high monocytes represent the main monocyte subset and give rise to vascular macrophages (Swirski et al., 2007). In mice, migration of Ly-6C $\mathrm{C}^{\text {high }}$ monocytes is regulated by an interaction of P-Selectin/PSGL-1 (An et al., 2008), VLA-4/VCAM-1 (Huo et al., 2001), Mac-1/CD40L (Wolf et al., 2011), and of CCR1 and -5 with their corresponding ligands (Tacke et al., 2007; Combadiere et al., 2008; Soehnlein et al., 2013). Notably, CCR1- but not CCR5-deficiency seems to protect only from early atherosclerosis in $A p o e^{-/-}$mice on a WD for 4 weeks, suggesting temporal differences in CCR-dependent leukocyte

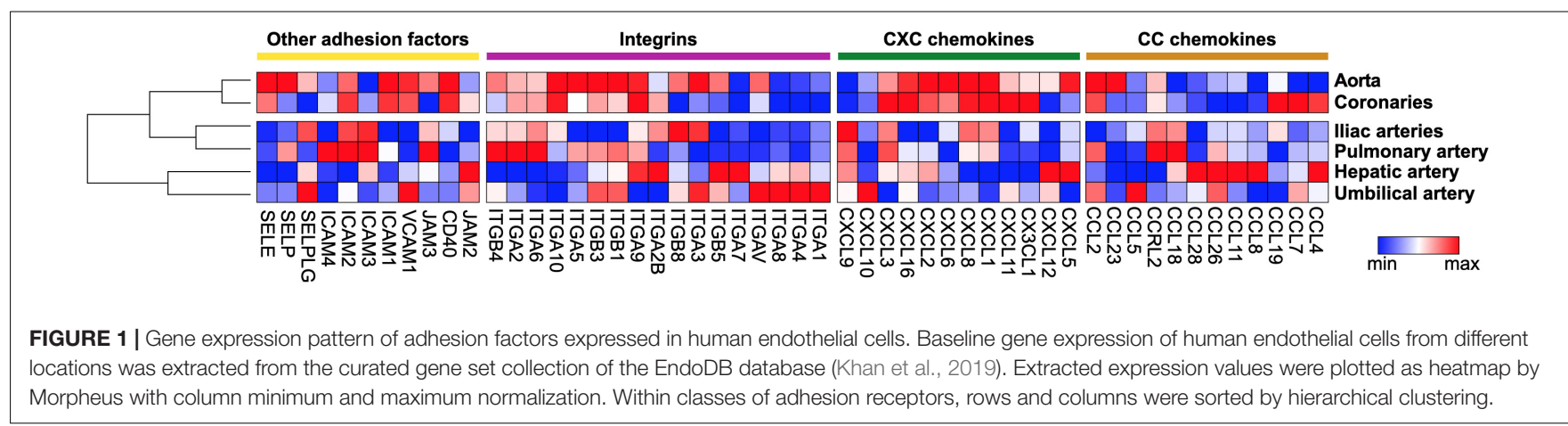




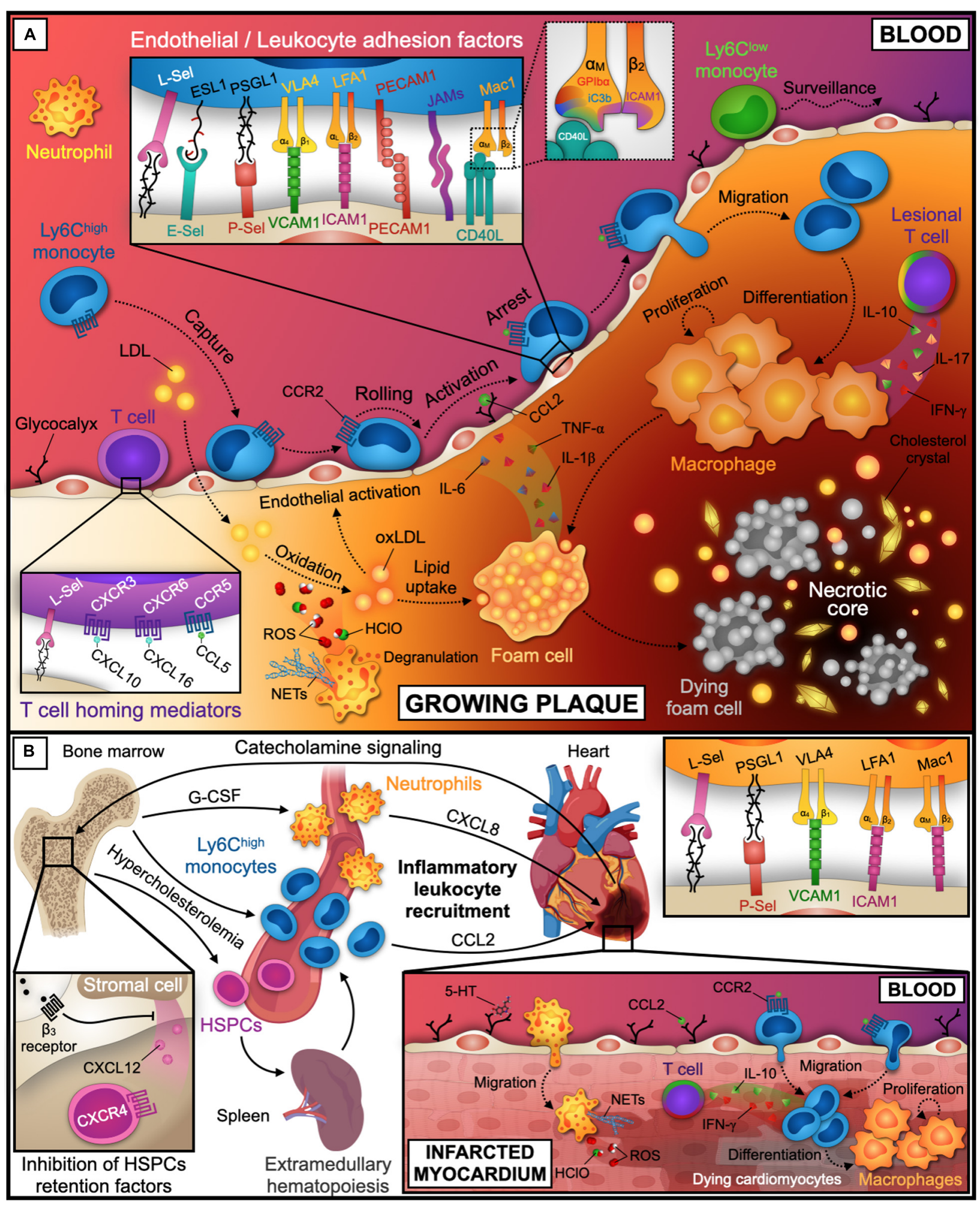

FIGURE 2 | Leukocyte recruitment into the atherosclerotic plaque and infarcted tissue. (A) Initial endothelial dysfunction and activation is promoted by shear stress at sites of turbulent blood flow and lipid accumulation. While Ly6 $\mathrm{C}^{\text {low }}$ monocytes patrol the endothelial surface for tissue surveillance, neutrophils and Ly6Chigh monocytes are recruited into the subendothelial space. Within the plaque, Ly6C $\mathrm{C}^{\mathrm{igh}}$ monocytes differentiate into macrophages. These proliferate, became foam cells, and orchestrate the inflammatory response, eventually die and build the necrotic core together with lipids and cholesterol crystals. These processes are further instructed by plaque-infiltrating T cells. Relevant inflammatory cytokines, chemokines, and receptor-ligand pairs for monocytes and T cells are indicated in the inlays. A third inlay shows CD4OL binding to a distinct site within the I-domain of $\alpha_{M}$ chain of Mac-1 that does not interfere with other Mac-1 ligands. (B) Coronary artery 


\section{FIGURE 2 | Continued}

occlusion precipitates $\mathrm{Ml}$ and triggers progenitor and inflammatory leukocyte release from the bone marrow by adrenergic signaling and decreased expression of the retention factors CXCL12 and CXCR4 in the bone marrow niche. CXCL8 and CCL2 guide neutrophils and Ly6Chigh monocytes to infarcted tissue. Neutrophils accumulate in the lesion by the adhesion factors depicted in the inlay and promote myocardial injury by reactive oxygen species (ROS), Hypochlorous acid ( $\mathrm{HClO}$ ), and NETs release. Ly6C ${ }^{\text {high }}$ monocytes are recruited and differentiate to macrophages. Tissue healing after MI is further modulated by infiltrated T cells that may secrete pro- or anti-inflammatory cytokines. LDL, low-density lipoprotein; oxLDL, oxidized LDL; Sel, Selectin; ESL1, E-Selectin Ligand 1; PSGL1, P-Selectin Glycoprotein Ligand 1; VCAM1, Vascular Cell Adhesion Molecule 1; VLA4, Very Late Antigen 4 ( $\left.\alpha_{4} \beta_{1}\right)$; ICAM1, Intercellular Adhesion Molecule 1; LFA1, Lymphocyte Function-associated Antigen 1 (CD11a/CD18, $\alpha_{L} \beta_{2}$ ); Mac1, Macrophage Receptor 1 (CD11b/CD18, $\left.\alpha_{M} \beta_{2}\right)$; PECAM1, Platelet/Endothelial Cell Adhesion Molecule 1; JAMs, Junctional Adhesion Molecules; CD40L, CD40 ligand; GPIb $\alpha$, Platelet Glycoprotein Ib $\alpha$; iC3b, inactive Complement component 3b; CCL, C-C Motif Chemokine Ligand; CXCL, C-X-C Motif Chemokine Ligand; CCR, C-C Motif Chemokine Receptor; CXCR, C-X-C Motif Chemokine Receptor; ROS, Reactive Oxygen Species; HCIO, Hypochlorous acid; NETs, Neutrophil Extracellular Traps; IL, Interleukin; TNF, Tumor Necrosis Factor; INF, Interferon; G-CSF, Granulocyte Colony-Stimulating Factor; HSPCs, Hematopoietic Stem and Progenitor Cells. The figure was generated with schematics from BioRender.com.

recruitment. While one report has excluded a role for CCR2 in classical monocyte recruitment (Soehnlein et al., 2013), other studies have highlighted that monocyte migration into the plaque and circadian rhythms of monocyte counts in the circulation are largely regulated by the CCR2-CCL2 axis (Boring et al., 1998; Tacke et al., 2007; Combadiere et al., 2008; Winter et al., 2018). Consistently, siRNA targeting CCR2 reduced the accumulation of Ly- $6 \mathrm{C}^{\text {high }}$ monocytes in the plaque and retards lesion progression in $A p o e^{-/-}$mice (Leuschner et al., 2011). Intraluminal crawling is regulated by the interaction of LFA-1 and Mac-1 with endothelial ICAMs (Schenkel et al., 2004). PECAM-1 and JAMs mediate transendothelial migration (Gerhardt and Ley, 2015).

\section{T Cells}

$\mathrm{T}$ cells represent the most abundant leukocyte lineage in atherosclerotic lesions (Winkels et al., 2018; Fernandez et al., 2019) and orchestrate inflammation by a variety of $\mathrm{T}$ cell cytokines with pro- (TNF- $\alpha$, IFN- $\gamma$, and IL-17) or anti- (IL10) atherogenic functions (Tedgui and Mallat, 2006). A part of lesional $\mathrm{T}$ cells recognizes self-antigens in LDL and its core protein, Apolipoprotein B (Wolf and Ley, 2019; Wolf et al., 2020) and exhibits mixed phenotypes of proatherogenic IFN- $\gamma$ secreting $\mathrm{T}_{\mathrm{H}} 1$ and IL-10 secreting regulatory $\mathrm{T}\left(\mathrm{T}_{\text {reg }}\right)$ cells. The contribution of other $\mathrm{T}_{\mathrm{H}}$ cell subsets, $\mathrm{CD} 8^{+}$, and $\gamma / \delta \mathrm{T}$ cells is less clear (Saigusa et al., 2020). Naïve and central memory, but not activated, $\mathrm{T}$ cells express L-Selectin for rolling on high endothelial venules (HEVs) and homing to lymph nodes (Weninger et al., 2001; Ley and Kansas, 2004). CCR7 acts as an homing guidance for lymph node entry of $\mathrm{T}$ cells (Worbs and Forster, 2007). T cell homing to mouse atherosclerotic lesions involves L-Selectin (Galkina et al., 2006) and CCL5/CCR5 (Li et al., 2016), CXCL10/CXCR3 (Mach et al., 1999), and CXCL16/CXCR6 (Wuttge et al., 2004): Decreased plaque size has been observed in $C c r 5^{-/-}$ (Braunersreuther et al., 2007), Cxcr3 ${ }^{-/-}$(Veillard et al., 2005), Cxcl10-/- (Heller et al., 2006), and $\mathrm{Cxcr6}^{-/-}$(Galkina et al., 2007) Apoe $-/-$ mice, which seems to be caused by reduced numbers of $\mathrm{T}_{\mathrm{H}} 1$ cells and increased $\mathrm{T}_{\text {reg }}$ numbers. Consistently, CCL5 (Braunersreuther et al., 2008), CCR5, and CXCR3 (van Wanrooij et al., 2005, 2008) antagonists are atheroprotective in mice. Apoe $e^{-/-}$mice deficient for CCR1, an alternative receptor for CCL5 (Braunersreuther et al., 2007), and Cxcl16 ${ }^{-/-}$ $L d l r^{-/-}$mice (Aslanian and Charo, 2006) develop enhanced atherosclerosis. The role of CCR7 and its ligands CCL19 and CCL21, which are detectable in atherosclerotic lesions from Apoe $e^{-/-}$mice and humans (Damas et al., 2007), has been controversial with contradictory findings (Luchtefeld et al., 2010; Wan et al., 2013). Many adhesion factors and chemokine receptors are expressed on myeloid cells and lymphocytes, which renders results from mice with whole-body genetic deficiencies difficult to interpret.

\section{Neutrophils}

Hypercholesterolemia and inflammation promote the expression of Granulocyte Colony-Stimulating Factor (G-CSF) in the bone marrow, which triggers a release of neutrophils (Drechsler et al., 2010). Neutrophils adhere to the endothelium in a Pand E-Selectin (Eriksson et al., 2001), and $\beta_{2}$ /ICAM dependent manner (Soehnlein, 2012). Neutrophil adhesion also involves platelet-derived CCL5 and CCR1 as well as CCR5 and CXCR2 (Drechsler et al., 2010), and leukotriene B4 binding to its highaffinity receptor BLT1 (Houard et al., 2009). Neutrophils can be detected in early and rupture-prone atherosclerotic plaques in Apoe $e^{-/-}$mice (Rotzius et al., 2010). Their depletion reduces atherosclerotic lesion size in $A p o e^{-/-}$mice (Drechsler et al., 2010). Lesional neutrophils correlate with disease progression (Drechsler et al., 2010), the release of reactive oxygen species (ROS) (Hosokawa et al., 2011), and the formation of neutrophil extracellular traps (NETs) in mice (Warnatsch et al., 2015; Folco et al., 2018). Neutrophils promote LDL oxidation (Podrez et al., 1999), favor monocyte recruitment (Zernecke et al., 2008), macrophage activation, and foam cell formation (Gombart et al., 2005). They may contribute to endothelial erosion and plaque destabilization by hypochlorous acid production from myeloperoxidase (MPO) (Naruko et al., 2002) and matrixdegrading proteases (MMPs) activity, such as MMP-9 (Leclercq et al., 2007; Soehnlein, 2012).

\section{INFLAMMATORY CELL RECRUITMENT AFTER MYOCARDIAL INFARCTION (MI)}

MI precipitates ischemic injury, cardiomyocyte death, and cardiac tissue remodeling and accelerates atherosclerosis by an activation of hematopoietic stem cells in the bone marrow niche and increased leukocyte production (Dutta et al., 2012; Figure 2B). In humans, neutrophils peak within the first $24 \mathrm{~h}$ 
after MI, likely by a G-CSF dependent response (Lieschke et al., 1994; Cannon et al., 2001; Zhang et al., 2015). Mouse neutrophils accumulate in the infarcted myocardium during the first 2 days after MI (Vafadarnejad et al., 2020) and contribute to ischemia/reperfusion injury by ROS release (Duilio et al., 2001), MPO activity (Askari et al., 2003), and NETs formation (Ge et al., 2015). Neutrophils are recruited by a process that involves CXCL8 (Sekido et al., 1993; Kukielka et al., 1995), plateletderived serotonin (Mauler et al., 2019), L- (Ma et al., 1993) and P-Selectins (Weyrich et al., 1993), PSGL-1 (Hayward et al., 1999), $\beta_{2}$ (CD18) integrins (Lu et al., 1997; Kempf et al., 2011), and ICAM-1 (Palazzo et al., 1998) in mice. While preclinical studies suggested that preventing neutrophil recruitment improves the clinical outcome after MI, anti-neutrophil therapy by blocking CD11b/CD18 has failed in clinical trials (Baran et al., 2001; Faxon et al., 2002). VLA4/VCAM-1 dependent migration (Bowden et al., 2002), a narrow therapeutic time window (Williams et al., 1994), and a potential interference with protective cell types mediating tissue reparation (Horckmans et al., 2017) may explain these negative results. Monocytes and macrophages represent the dominating hematopoietic cell types in the healthy and infarcted heart (Farbehi et al., 2019) and participate in tissue healing and inflammation. Peripheral monocytosis has been associated with impaired myocardial healing in humans (Maekawa et al., 2002; van der Laan et al., 2014). While monocyte depletion abolishes tissue regeneration (van Amerongen et al., 2007), hypercholesterolemia-induced Ly-6 $C^{\text {high }}$ monocytosis accelerates cardiac remodeling and the development of heart failure in $A p o e^{-/-}$mice (Panizzi et al., 2010). Ly-6Chigh monocytes are recruited into the heart via CCR2 and CCL2, CCL7 (Kaikita et al., 2004; Dewald et al., 2005) as well as by VCAM1-depedent mechanisms (Nahrendorf et al., 2009). B cells in the infracted heart may serve as source of CCL7 (Zouggari et al., 2013). siRNA targeting CCR2 (Majmudar et al., 2013), bone marrow endothelial cellexpressed CCL2 (Krohn-Grimberghe et al., 2020), or endothelial adhesion molecules (Sager et al., 2016a) reduces Ly-6C $\mathrm{C}^{\text {high }}$ monocyte accumulation in infarcted tissue in mice. Together with neutrophils, Ly-6C ${ }^{\text {high }}$ monocytes contribute to the phagocytosis of dead and dying cardiomyocytes and secrete extracellular matrix proteases and pro-inflammatory cytokines (Nahrendorf et al., 2007). While neutrophils do not persist in infarcted tissue (Dewald et al., 2004; Yan et al., 2013), monocytes continue to accumulate and give rise to early inflammatory macrophages (Nahrendorf, 2018). 5-10 days after MI, a second set of monocytes expressing Ly6 $\mathrm{C}^{\text {low }}$ accumulate in a CX3CR1dependent manner (Nahrendorf et al., 2007) but can also stem

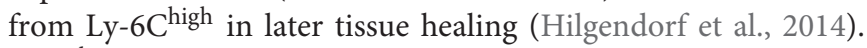
Ly6 $\mathrm{C}^{\text {low }}$ monocytes primarily involve in tissue healing and may be instructed by protective regulatory $\mathrm{T}\left(\mathrm{T}_{\text {reg }}\right)$ cell-derived IL10 (Weirather et al., 2014) or pro-inflammatory $\mathrm{T}$ cell expressing IFN- $\gamma$ (Yang et al., 2006). The role of other chemokine ligands highly expressed in the infarcted heart, such as CCL3 and CCL4, remains unclear (Frangogiannis and Entman, 2005). In addition to traditional cardiovascular risk factors, environmental stressors (e.g., air pollutants) enhance inflammatory leukocyte recruitment to the infarcted myocardium by an upregulation of endothelial ICAM-1 and VCAM-1, Mac-1 activation, and the release of pro-inflammatory cytokines from macrophages (Marchini et al., 2016).

\section{CLINICAL TRANSLATION AND CONCLUDING REMARKS}

The inflammatory nature of atherosclerosis and MI has been established by many clinical and pre-clinical studies (Libby, 2002). Several novel therapeutic concepts targeting inflammation and immunity have arisen from this work (Libby and Everett, 2019). Consequently, the inhibition of receptors and ligands involved in the generation, adhesion, and transmigration of leukocytes has revealed a great potential for anti-leukocyte therapies at the preclinical stage. In contrast, clinical evidence has remained on a premature stage. Clinical studies indicate that leukocyte counts (Madjid et al., 2004; Adamstein et al., 2021) correlate with the appearance of MI and clinical atherosclerosis. In addition, atherosclerotic plaque size (Stone et al., 2011) and the accumulation of some, specialized leukocyte subsets predict complicated disease (Fernandez et al., 2019). However, only a few clinical studies have directly tested anti-leukocyte therapies: Administration of the P-Selectin blocking antibody Inclacumab prevented myocardial damage after $\mathrm{MI}$ and a percutaneous coronary intervention (PCI) (Tardif et al., 2013; Stahli et al., 2016). A neutralization of MCP-1 (CCL2) with antibodies and gene therapy showed effective in the prevention of leukocyte recruitment in atherosclerotic vessels after PCI in primates (Horvath et al., 2002; Ohtani et al., 2004). Likewise, a depletion of monocytes by liposomal alendronate partially reduced stent restenosis (Banai et al., 2013). On the other hand, inhibition of the chemokine MCP-1 (CCL2) with the compound Bindarit failed to reduce coronary restenosis following PCI and had no effect on major cardiovascular events (Colombo et al., 2016). Administration of the CCR2 blocking antibody MLN1202 proved safety in individuals at a high atherosclerotic risk. A single nucleotide polymorphism at the MCP-1 promoter region was associated with reduced high-sensitivity $\mathrm{C}$-reactive protein levels (Gilbert et al., 2011), but effects on atherosclerotic lesions or cardiovascular outcomes have not been evaluated in this study. Recently, the CCR5 antagonist Maraviroc was shown to reduce atherosclerosis progression in HIV patients (Francisci et al., 2019).

Several conceptual challenges render the direct translation into cardiovascular medical therapies difficult. A lack of tissuetropism remains the leading limitation. In contrast to an inhibition of the integrins $\alpha_{4} \beta_{7}$ and $\alpha_{E} \beta_{7}$ during IBD (Ley et al., 2016), it is unclear which adhesion receptors specifically mediate leukocyte recruitment to atherosclerotic plaques or the heart. An unspecific inhibition of homing factors involved in host-defense, tissue healing, and regeneration is at the risk to induce severe side effects. This is best documented by $\beta_{2}$-integrins such as Mac-1 and LFA-1 that mediates a variety of beneficial and pathogenic effects. A genetic mutation of the $\beta_{2}$-subunit in humans causes the severe immunodeficiency Leukocyte-Adhesion Deficiency (LAD). In addition, small molecule $\beta_{2}$-integrin inhibitors 
and antibodies have caused the potentially fatal complication, Progressive Multifocal Leukoencephalopathy (PML) that is likely caused by a reactivation of John Cunningham Virus (JCV) in the central nervous system (Berger and Houff, 2010). Recent preclinical studies suggest that this problem could be overcome by a ligand-specific inhibition, as demonstrated for the $\alpha$-subunit of Mac-1 to specifically interfere with the binding of some ligands involved in the interaction with platelets or the endothelium, but not others (Ehlers et al., 2003; Wang et al., 2005; Wolf et al., 2011, 2018). In contrast, inhibition of platelet integrins has successfully been used in cardiovascular medicine for antithrombotic therapy (Ley et al., 2016). The widespread clinical application of tolerable and highly effective anti-chemokine (Mollica Poeta et al., 2019) and anti-integrin therapies (RaabWestphal et al., 2017) in inflammatory disease and cancer, however, holds the potential of future clinical trials to combat cardiovascular pathologies.

\section{REFERENCES}

Adamstein, N. H., MacFadyen, J. G., Rose, L. M., Glynn, R. J., Dey, A. K., Libby, P., et al. (2021). The neutrophil-lymphocyte ratio and incident atherosclerotic events: analyses from five contemporary randomized trials. Eur. Heart J. ehaa1034. [Epub ahead of print].

An, G., Wang, H., Tang, R., Yago, T., McDaniel, J. M., McGee, S., et al. (2008). Pselectin glycoprotein ligand-1 is highly expressed on Ly-6Chi monocytes and a major determinant for Ly-6Chi monocyte recruitment to sites of atherosclerosis in mice. Circulation 117, 3227-3237. doi: 10.1161/circulationaha.108.771048

Ancuta, P., Liu, K. Y., Misra, V., Wacleche, V. S., Gosselin, A., Zhou, X., et al. (2009). Transcriptional profiling reveals developmental relationship and distinct biological functions of CD16+ and CD16- monocyte subsets. BMC Genomics 10:403. doi: 10.1186/1471-2164-10-403

Arnaout, M. A., Mahalingam, B., and Xiong, J. P. (2005). Integrin structure, allostery, and bidirectional signaling. Annu. Rev. Cell Dev. Biol. 21, 381-410. doi: 10.1146/annurev.cellbio.21.090704.151217

Askari, A. T., Brennan, M. L., Zhou, X., Drinko, J., Morehead, A., Thomas, J. D., et al. (2003). Myeloperoxidase and plasminogen activator inhibitor 1 play a central role in ventricular remodeling after myocardial infarction. J. Exp. Med. 197, 615-624. doi: 10.1084/jem.20021426

Aslanian, A. M., and Charo, I. F. (2006). Targeted disruption of the scavenger receptor and chemokine CXCL16 accelerates atherosclerosis. Circulation 114, 583-590. doi: 10.1161/circulationaha.105.540583

Auffray, C., Fogg, D., Garfa, M., Elain, G., Join-Lambert, O., Kayal, S., et al. (2007). Monitoring of blood vessels and tissues by a population of monocytes with patrolling behavior. Science 317, 666-670. doi: 10.1126/science.1142883

Banai, S., Finkelstein, A., Almagor, Y., Assali, A., Hasin, Y., Rosenschein, U., et al. (2013). Targeted anti-inflammatory systemic therapy for restenosis: the Biorest Liposomal Alendronate with Stenting sTudy (BLAST)-a double blind, randomized clinical trial. Am. Heart J. 165, 234-240.e1.

Baran, K. W., Nguyen, M., McKendall, G. R., Lambrew, C. T., Dykstra, G., Palmeri, S. T., et al. (2001). Double-blind, randomized trial of an anti-CD18 antibody in conjunction with recombinant tissue plasminogen activator for acute myocardial infarction: limitation of myocardial infarction following thrombolysis in acute myocardial infarction (LIMIT AMI) study. Circulation 104, 2778-2783. doi: 10.1161/hc4801.100236

Berger, J. R., and Houff, S. A. (2010). Neurological infections: the year of PML and influenza. Lancet Neurol. 9, 14-17. doi: 10.1016/s1474-4422(09)70337-0

Berlin, C., Bargatze, R. F., Campbell, J. J., von Andrian, U. H., Szabo, M. C., Hasslen, S. R., et al. (1995). alpha 4 integrins mediate lymphocyte attachment and rolling under physiologic flow. Cell 80, 413-422. doi: 10.1016/0092-8674(95)90491-3

Boring, L., Gosling, J., Cleary, M., and Charo, I. F. (1998). Decreased lesion formation in CCR2-/- mice reveals a role for chemokines in the initiation of atherosclerosis. Nature 394, 894-897. doi: 10.1038/29788

\section{AUTHOR CONTRIBUTIONS}

All authors listed made a substantial, direct and intellectual contribution to this work, and approved it for publication.

\section{FUNDING}

TM was supported by a fellowship from the German Academic Exchange Service (DAAD) and a research grant from the Agencia Nacional de Promoción Científica y Tecnológica (PICT 20163062) of Argentina. This study was funded by the Deutsche Forschungsgemeinschaft (DFG, German Research Foundation), SFB1425, project \#422681845. This project has received funding from the European Research Council (ERC) under the European Union's Horizon 2020 Research and Innovation Program (grant agreement No. 853425).

Bowden, R. A., Ding, Z. M., Donnachie, E. M., Petersen, T. K., Michael, L. H., Ballantyne, C. M., et al. (2002). Role of alpha4 integrin and VCAM-1 in CD18independent neutrophil migration across mouse cardiac endothelium. Circ. Res. 90, 562-569. doi: 10.1161/01.res.0000013835.53611.97

Braunersreuther, V., Steffens, S., Arnaud, C., Pelli, G., Burger, F., Proudfoot, A., et al. (2008). A novel RANTES antagonist prevents progression of established atherosclerotic lesions in mice. Arterioscler. Thromb. Vasc. Biol. 28, 1090-1096. doi: 10.1161/atvbaha.108.165423

Braunersreuther, V., Zernecke, A., Arnaud, C., Liehn, E. A., Steffens, S., Shagdarsuren, E., et al. (2007). Ccr5 but not Ccr1 deficiency reduces development of diet-induced atherosclerosis in mice. Arterioscler. Thromb. Vasc. Biol. 27, 373-379. doi: 10.1161/01.atv.0000253886.44609.ae

Braunwald, E. (2012). The treatment of acute myocardial infarction: the past, the present, and the future. Eur. Heart J. Acute Cardiovasc. Care 1, 9-12. doi: $10.1177 / 2048872612438026$

Briskin, M. J., McEvoy, L. M., and Butcher, E. C. (1993). MAdCAM-1 has homology to immunoglobulin and mucin-like adhesion receptors and to IgA1. Nature 363, 461-464. doi: 10.1038/363461a0

Cannon, C. P., McCabe, C. H., Wilcox, R. G., Bentley, J. H., and Braunwald, E. (2001). Association of white blood cell count with increased mortality in acute myocardial infarction and unstable angina pectoris. OPUS-TIMI 16 Investigators. Am. J. Cardiol. 87, 636-639, A10.

Collins, R. G., Velji, R., Guevara, N. V., Hicks, M. J., Chan, L., and Beaudet, A. L. P. - (2000). Selectin or intercellular adhesion molecule (ICAM)-1 deficiency substantially protects against atherosclerosis in apolipoprotein E-deficient mice. J. Exp. Med. 191, 189-194. doi: 10.1084/jem.191.1.189

Colombo, A., Basavarajaiah, S., Limbruno, U., Picchi, A., Lettieri, C., Valgimigli, M., et al. (2016). A double-blind randomised study to evaluate the efficacy and safety of bindarit in preventing coronary stent restenosis. EuroIntervention 12, e1385-e1394.

Combadiere, C., Potteaux, S., Rodero, M., Simon, T., Pezard, A., Esposito, B., et al. (2008). Combined inhibition of CCL2, CX3CR1, and CCR5 abrogates Ly6C(hi) and Ly6C(lo) monocytosis and almost abolishes atherosclerosis in hypercholesterolemic mice. Circulation 117, 1649-1657. doi: 10.1161/ circulationaha.107.745091

Couffinhal, T., Duplaa, C., Moreau, C., Lamaziere, J. M., and Bonnet, J. (1994). Regulation of vascular cell adhesion molecule-1 and intercellular adhesion molecule-1 in human vascular smooth muscle cells. Circ. Res. 74, 225-234. doi: 10.1161/01.res.74.2.225

Courties, G., Herisson, F., Sager, H. B., Heidt, T., Ye, Y., Wei, Y., et al. (2015). Ischemic stroke activates hematopoietic bone marrow stem cells. Circ. Res. 116, 407-417. doi: 10.1161/circresaha.116.305207

Cybulsky, M. I., Iiyama, K., Li, H., Zhu, S., Chen, M., Iiyama, M., et al. (2001). A major role for VCAM-1, but not ICAM-1, in early atherosclerosis. J. Clin. Invest. 107, 1255-1262. doi: $10.1172 /$ jci11871 
da Costa Martins, P., Garcia-Vallejo, J. J., van Thienen, J. V., Fernandez-Borja, M., van, Gils JM, Beckers, C., et al. (2007). P-selectin glycoprotein ligand-1 is expressed on endothelial cells and mediates monocyte adhesion to activated endothelium. Arterioscler. Thromb. Vasc. Biol. 27, 1023-1029. doi: 10.1161/ atvbaha.107.140442

Damas, J. K., Smith, C., Oie, E., Fevang, B., Halvorsen, B., Waehre, T., et al. (2007). Enhanced expression of the homeostatic chemokines CCL19 and CCL21 in clinical and experimental atherosclerosis: possible pathogenic role in plaque destabilization. Arterioscler. Thromb. Vasc. Biol. 27, 614-620. doi: 10.1161/01. atv.0000255581.38523.7c

Davies, M. J., Gordon, J. L., Gearing, A. J., Pigott, R., Woolf, N., Katz, D., et al. (1993). The expression of the adhesion molecules ICAM-1, VCAM-1, PECAM, and E-selectin in human atherosclerosis. J. Pathol. 171, 223-229. doi: 10.1002/ path.1711710311

Davignon, J., and Ganz, P. (2004). Role of endothelial dysfunction in atherosclerosis. Circulation 109(23 Suppl. 1), III27-III32.

Dewald, O., Ren, G., Duerr, G. D., Zoerlein, M., Klemm, C., Gersch, C., et al. (2004). Of mice and dogs: species-specific differences in the inflammatory response following myocardial infarction. Am. J. Pathol. 164, 665-677.

Dewald, O., Zymek, P., Winkelmann, K., Koerting, A., Ren, G., Abou-Khamis, T., et al. (2005). CCL2/Monocyte Chemoattractant Protein-1 regulates inflammatory responses critical to healing myocardial infarcts. Circ. Res. 96, 881-889. doi: 10.1161/01.res.0000163017.13772.3a

Dong, Z. M., Brown, A. A., and Wagner, D. D. (2000). Prominent role of P-selectin in the development of advanced atherosclerosis in ApoE-deficient mice. Circulation 101, 2290-2295. doi: 10.1161/01.cir.101.19.2290

Dong, Z. M., Chapman, S. M., Brown, A. A., Frenette, P. S., Hynes, R. O., and Wagner, D. D. (1998). The combined role of P- and E-selectins in atherosclerosis. J. Clin. Invest. 102, 145-152. doi: 10.1172/jci3001

Doring, Y., Noels, H., Mandl, M., Kramp, B., Neideck, C., Lievens, D., et al. (2014). Deficiency of the sialyltransferase St3Gal4 reduces Ccl5-mediated myeloid cell recruitment and arrest: short communication. Circ. Res. 114, 976-981. doi: 10.1161/circresaha.114.302426

Drechsler, M., Megens, R. T., van Zandvoort, M., Weber, C., and Soehnlein, O. (2010). Hyperlipidemia-triggered neutrophilia promotes early atherosclerosis. Circulation 122, 1837-1845. doi: 10.1161/circulationaha.110.961714

Duilio, C., Ambrosio, G., Kuppusamy, P., DiPaula, A., Becker, L. C., and Zweier, J. L. (2001). Neutrophils are primary source of $\mathrm{O} 2$ radicals during reperfusion after prolonged myocardial ischemia. Am. J. Physiol. Heart Circ. Physiol. 280, H2649-H2657.

Dunne, J. L., Collins, R. G., Beaudet, A. L., Ballantyne, C. M., and Ley, K. (2003). Mac-1, but not LFA-1, uses intercellular adhesion molecule-1 to mediate slow leukocyte rolling in TNF-alpha-induced inflammation. J. Immunol. 171, 6105-6111. doi: 10.4049/jimmunol.171.11.6105

Dutta, P., Courties, G., Wei, Y., Leuschner, F., Gorbatov, R., Robbins, C. S., et al. (2012). Myocardial infarction accelerates atherosclerosis. Nature 487, 325-329.

Ehlers, R., Ustinov, V., Chen, Z., Zhang, X., Rao, R., Luscinskas, F. W., et al. (2003). Targeting platelet-leukocyte interactions: identification of the integrin Mac-1 binding site for the platelet counter receptor glycoprotein Ibalpha. J. Exp. Med. 198, 1077-1088.

Ensan, S., Li, A., Besla, R., Degousee, N., Cosme, J., Roufaiel, M., et al. (2016). Self-renewing resident arterial macrophages arise from embryonic CX3CR1(+) precursors and circulating monocytes immediately after birth. Nat. Immunol. 17, 159-168. doi: 10.1038/ni.3343

Epelman, S., Liu, P. P., and Mann, D. L. (2015). Role of innate and adaptive immune mechanisms in cardiac injury and repair. Nat. Rev. Immunol. 15, 117-129. doi: $10.1038 /$ nri3800

Eriksson, E. E., Xie, X., Werr, J., Thoren, P., and Lindbom, L. (2001). Direct viewing of atherosclerosis in vivo: plaque invasion by leukocytes is initiated by the endothelial selectins. FASEB J. 15, 1149-1157. doi: 10.1096/fj.00-0537com

Fan, Z., and Ley, K. (2015). Leukocyte arrest: biomechanics and molecular mechanisms of beta2 integrin activation. Biorheology 52, 353-377. doi: 10.3233/ bir- 15085

Fan, Z., McArdle, S., Marki, A., Mikulski, Z., Gutierrez, E., Engelhardt, B., et al. (2016). Neutrophil recruitment limited by high-affinity bent beta2 integrin binding ligand in cis. Nat. Commun. 7:12658.

Farbehi, N., Patrick, R., Dorison, A., Xaymardan, M., Janbandhu, V., Wystub-Lis, K., et al. (2019). Single-cell expression profiling reveals dynamic flux of cardiac stromal, vascular and immune cells in health and injury. Elife 8:e43882.
Faxon, D. P., Gibbons, R. J., Chronos, N. A., Gurbel, P. A., Sheehan, F., and Investigators, H.-M. (2002). The effect of blockade of the CD11/CD18 integrin receptor on infarct size in patients with acute myocardial infarction treated with direct angioplasty: the results of the HALT-MI study. J. Am. Coll. Cardiol. 40, 1199-1204. doi: 10.1016/s0735-1097(02)02136-8

Fernandez, D. M., Rahman, A. H., Fernandez, N. F., Chudnovskiy, A., Amir, E. D., Amadori, L., et al. (2019). Single-cell immune landscape of human atherosclerotic plaques. Nat. Med. 25, 1576-1588.

Finney, A. C., Stokes, K. Y., Pattillo, C. B., and Orr, A. W. (2017). Integrin signaling in atherosclerosis. Cell. Mol. Life Sci. 74, 2263-2282. doi: 10.1007/s00018-0172490-4

Folco, E. J., Mawson, T. L., Vromman, A., Bernardes-Souza, B., Franck, G., Persson, O., et al. (2018). Neutrophil extracellular traps induce endothelial cell activation and tissue factor production through interleukin-1alpha and cathepsin G. Arterioscler. Thromb. Vasc. Biol. 38, 1901-1912. doi: 10.1161/atvbaha.118. 311150

Francisci, D., Pirro, M., Schiaroli, E., Mannarino, M. R., Cipriani, S., Bianconi, V., et al. (2019). Maraviroc intensification modulates atherosclerotic progression in HIV-suppressed patients at high cardiovascular risk. A randomized, crossover pilot study. Open Forum Infect. Dis. 6:ofz112.

Frangogiannis, N. G., and Entman, M. L. (2005). Chemokines in myocardial ischemia. Trends Cardiovasc. Med. 15, 163-169. doi: 10.2174/157016104347 6375

Galkina, E., Harry, B. L., Ludwig, A., Liehn, E. A., Sanders, J. M., Bruce, A., et al. (2007). CXCR6 promotes atherosclerosis by supporting T-cell homing, interferon-gamma production, and macrophage accumulation in the aortic wall. Circulation 116, 1801-1811. doi: 10.1161/circulationaha.106.678474

Galkina, E., Kadl, A., Sanders, J., Varughese, D., Sarembock, I. J., and Ley, K. (2006). Lymphocyte recruitment into the aortic wall before and during development of atherosclerosis is partially L-selectin dependent. J. Exp. Med. 203, 1273-1282. doi: 10.1084 /jem.20052205

Galkina, E., and Ley, K. (2007a). Leukocyte influx in atherosclerosis. Curr. Drug Targets 8, 1239-1248. doi: 10.2174/138945007783220650

Galkina, E., and Ley, K. (2007b). Vascular adhesion molecules in atherosclerosis. Arterioscler. Thromb. Vasc. Biol. 27, 2292-2301. doi: 10.1161/atvbaha.107. 149179

Ge, L., Zhou, X., Ji, W. J., Lu, R. Y., Zhang, Y., Zhang, Y. D., et al. (2015). Neutrophil extracellular traps in ischemia-reperfusion injury-induced myocardial noreflow: therapeutic potential of DNase-based reperfusion strategy. Am. J. Physiol. Heart Circ. Physiol. 308, H500-H509.

Gebuhrer, V., Murphy, J. F., Bordet, J. C., Reck, M. P., and McGregor, J. L. (1995). Oxidized low-density lipoprotein induces the expression of P-selectin (GMP140/PADGEM/CD62) on human endothelial cells. Biochem. J. 306(Pt 1), 293-298. doi: 10.1042/bj3060293

Gerhardt, T., and Ley, K. (2015). Monocyte trafficking across the vessel wall. Cardiovasc. Res. 107, 321-330. doi: 10.1093/cvr/cvv147

Gilbert, J., Lekstrom-Himes, J., Donaldson, D., Lee, Y., Hu, M., Xu, J., et al. (2011). Effect of CC chemokine receptor 2 CCR2 blockade on serum C-reactive protein in individuals at atherosclerotic risk and with a single nucleotide polymorphism of the monocyte chemoattractant protein-1 promoter region. Am. J. Cardiol. 107, 906-911. doi: 10.1016/j.amjcard.2010.11.005

Gombart, A. F., Krug, U., O’Kelly, J., An, E., Vegesna, V., and Koeffler, H. P. (2005). Aberrant expression of neutrophil and macrophage-related genes in a murine model for human neutrophil-specific granule deficiency. J. Leukoc. Biol. 78, 1153-1165. doi: 10.1189/jlb.0504286

Graham, G. J., Handel, T. M., and Proudfoot, A. E. I. (2019). Leukocyte adhesion: reconceptualizing chemokine presentation by glycosaminoglycans. Trends Immunol. 40, 472-481. doi: 10.1016/j.it.2019.03.009

Hayward, R., Campbell, B., Shin, Y. K., Scalia, R., and Lefer, A. M. (1999). Recombinant soluble P-selectin glycoprotein ligand-1 protects against myocardial ischemic reperfusion injury in cats. Cardiovasc. Res. 41, 65-76. doi: 10.1016/s0008-6363(98)00266-1

Heidt, T., Courties, G., Dutta, P., Sager, H. B., Sebas, M., Iwamoto, Y., et al. (2014a). Differential contribution of monocytes to heart macrophages in steadystate and after myocardial infarction. Circ. Res. 115, 284-295. doi: 10.1161/ circresaha.115.303567

Heidt, T., Sager, H. B., Courties, G., Dutta, P., Iwamoto, Y., Zaltsman, A., et al. (2014b). Chronic variable stress activates hematopoietic stem cells. Nat. Med. 20, 754-758. doi: $10.1038 / \mathrm{nm} .3589$ 
Heller, E. A., Liu, E., Tager, A. M., Yuan, Q., Lin, A. Y., Ahluwalia, N., et al. (2006). Chemokine CXCL10 promotes atherogenesis by modulating the local balance of effector and regulatory T cells. Circulation 113, 2301-2312. doi: 10.1161/circulationaha.105.605121

Higgins, J. M., Mandlebrot, D. A., Shaw, S. K., Russell, G. J., Murphy, E. A., Chen, Y. T., et al. (1998). Direct and regulated interaction of integrin alphaEbeta7 with E-cadherin. J. Cell Biol. 140, 197-210. doi: 10.1083/jcb.140.1.197

Hilgendorf, I., Gerhardt, L. M., Tan, T. C., Winter, C., Holderried, T. A., Chousterman, B. G., et al. (2014). Ly-6Chigh monocytes depend on Nr4al to balance both inflammatory and reparative phases in the infarcted myocardium. Circ. Res. 114, 1611-1622. doi: 10.1161/circresaha.114.303204

Horckmans, M., Ring, L., Duchene, J., Santovito, D., Schloss, M. J., Drechsler, M., et al. (2017). Neutrophils orchestrate post-myocardial infarction healing by polarizing macrophages towards a reparative phenotype. Eur. Heart J. 38, 187-197.

Horvath, C., Welt, F. G., Nedelman, M., Rao, P., and Rogers, C. (2002). Targeting CCR2 or CD18 inhibits experimental in-stent restenosis in primates: inhibitory potential depends on type of injury and leukocytes targeted. Circ. Res. 90, 488-494. doi: 10.1161/hh0402.105956

Hosokawa, T., Kumon, Y., Kobayashi, T., Enzan, H., Nishioka, Y., Yuri, K., et al. (2011). Neutrophil infiltration and oxidant-production in human atherosclerotic carotid plaques. Histol. Histopathol. 26, 1-11. doi: 10.1111/j. 1552-6569.2012.00705.x

Houard, X., Touat, Z., Ollivier, V., Louedec, L., Philippe, M., Sebbag, U., et al. (2009). Mediators of neutrophil recruitment in human abdominal aortic aneurysms. Cardiovasc. Res. 82, 532-541. doi: 10.1093/cvr/cvp048

Huo, Y., Weber, C., Forlow, S. B., Sperandio, M., Thatte, J., Mack, M., et al. (2001). The chemokine $\mathrm{KC}$, but not monocyte chemoattractant protein-1, triggers monocyte arrest on early atherosclerotic endothelium. J. Clin. Invest. 108, 1307-1314. doi: 10.1172/jci12877

Johnson, R. C., Chapman, S. M., Dong, Z. M., Ordovas, J. M., Mayadas, T. N., Herz, J., et al. (1997). Absence of P-selectin delays fatty streak formation in mice. J. Clin. Invest. 99, 1037-1043. doi: 10.1172/jci119231

Johnson-Tidey, R. R., McGregor, J. L., Taylor, P. R., and Poston, R. N. (1994). Increase in the adhesion molecule P-selectin in endothelium overlying atherosclerotic plaques. Coexpression with intercellular adhesion molecule-1. Am. J. Pathol. 144, 952-961.

Jongstra-Bilen, J., Haidari, M., Zhu, S. N., Chen, M., Guha, D., and Cybulsky, M. I. (2006). Low-grade chronic inflammation in regions of the normal mouse arterial intima predisposed to atherosclerosis. J. Exp. Med. 203, 2073-2083. doi: $10.1084 /$ jem. 20060245

Kaikita, K., Hayasaki, T., Okuma, T., Kuziel, W. A., Ogawa, H., and Takeya, M. (2004). Targeted deletion of CC chemokine receptor 2 attenuates left ventricular remodeling after experimental myocardial infarction. Am. J. Pathol. 165, 439447. doi: 10.1016/s0002-9440(10)63309-3

Kempf, T., Zarbock, A., Widera, C., Butz, S., Stadtmann, A., Rossaint, J., et al. (2011). GDF-15 is an inhibitor of leukocyte integrin activation required for survival after myocardial infarction in mice. Nat. Med. 17, 581-588. doi: 10. 1038/nm.2354

Khan, S., Taverna, F., Rohlenova, K., Treps, L., Geldhof, V., de Rooij, L., et al. (2019). EndoDB: a database of endothelial cell transcriptomics data. Nucleic Acids Res. 47, D736-D744.

Kita, T., Kume, N., Minami, M., Hayashida, K., Murayama, T., Sano, H., et al. (2001). Role of oxidized LDL in atherosclerosis. Ann. N. Y. Acad. Sci. 947, 199-205; discussion -6.

Koltsova, E. K., Garcia, Z., Chodaczek, G., Landau, M., McArdle, S., Scott, S. R., et al. (2012). Dynamic T cell-APC interactions sustain chronic inflammation in atherosclerosis. J. Clin. Invest. 122, 3114-3126. doi: 10.1172/jci61758

Krohn-Grimberghe, M., Mitchell, M. J., Schloss, M. J., Khan, O. F., Courties, G., Guimaraes, P. P. G., et al. (2020). Nanoparticle-encapsulated siRNAs for gene silencing in the haematopoietic stem-cell niche. Nat. Biomed. Eng. 4, 1076-1089. doi: 10.1038/s41551-020-00623-7

Kukielka, G. L., Smith, C. W., LaRosa, G. J., Manning, A. M., Mendoza, L. H., Daly, T. J., et al. (1995). Interleukin-8 gene induction in the myocardium after ischemia and reperfusion in vivo. J. Clin. Invest. 95, 89-103. doi: 10.1172/ jci117680

Leclercq, A., Houard, X., Philippe, M., Ollivier, V., Sebbag, U., Meilhac, O., et al. (2007). Involvement of intraplaque hemorrhage in atherothrombosis evolution via neutrophil protease enrichment. J. Leukoc. Biol. 82, 1420-1429. doi: 10. 1189/jlb.1106671

Leistner, D. M., Krankel, N., Meteva, D., Abdelwahed, Y. S., Seppelt, C., Stahli, B. E., et al. (2020). Differential immunological signature at the culprit site distinguishes acute coronary syndrome with intact from acute coronary syndrome with ruptured fibrous cap: results from the prospective translational OPTICO-ACS study. Eur. Heart J. 41, 3549-3560. doi: 10.1093/eurheartj/ ehaa703

Leuschner, F., Dutta, P., Gorbatov, R., Novobrantseva, T. I., Donahoe, J. S., Courties, G., et al. (2011). Therapeutic siRNA silencing in inflammatory monocytes in mice. Nat. Biotechnol. 29, 1005-1010.

Levinovitz, A., Muhlhoff, J., Isenmann, S., and Vestweber, D. (1993). Identification of a glycoprotein ligand for E-selectin on mouse myeloid cells. J. Cell Biol. 121, 449-459. doi: 10.1083/jcb.121.2.449

Ley, K., and Huo, Y. (2001). VCAM-1 is critical in atherosclerosis. J. Clin. Invest. 107, 1209-1210. doi: 10.1172/jci13005

Ley, K., and Kansas, G. S. (2004). Selectins in T-cell recruitment to non-lymphoid tissues and sites of inflammation. Nat. Rev. Immunol. 4, 325-335. doi: 10.1038/ nri1351

Ley, K., Laudanna, C., Cybulsky, M. I., and Nourshargh, S. (2007). Getting to the site of inflammation: the leukocyte adhesion cascade updated. Nat. Rev. Immunol. 7, 678-689. doi: 10.1038/nri2156

Ley, K., Rivera-Nieves, J., Sandborn, W. J., and Shattil, S. (2016). Integrin-based therapeutics: biological basis, clinical use and new drugs. Nat. Rev. Drug Discov. 15, 173-183. doi: 10.1038/nrd.2015.10

Li, J., McArdle, S., Gholami, A., Kimura, T., Wolf, D., Gerhardt, T., et al. (2016). CCR5+T-bet+FoxP3+ effector CD4 T cells drive atherosclerosis. Circ. Res. 118, 1540-1552. doi: 10.1161/circresaha.116.308648

Libby, P. (2002). Inflammation in atherosclerosis. Nature 420, 868-874.

Libby, P., and Everett, B. M. (2019). Novel antiatherosclerotic therapies. Arterioscler. Thromb. Vasc. Biol. 39, 538-545. doi: 10.1161/atvbaha.118.310958

Lieschke, G. J., Grail, D., Hodgson, G., Metcalf, D., Stanley, E., Cheers, C., et al. (1994). Mice lacking granulocyte colony-stimulating factor have chronic neutropenia, granulocyte and macrophage progenitor cell deficiency, and impaired neutrophil mobilization. Blood 84, 1737-1746. doi: 10.1182/blood. v84.6.1737.1737

Lu, H., Smith, C. W., Perrard, J., Bullard, D., Tang, L., Shappell, S. B., et al. (1997). LFA-1 is sufficient in mediating neutrophil emigration in Mac-1-deficient mice. J. Clin. Invest. 99, 1340-1350. doi: 10.1172/jci119293

Luchtefeld, M., Grothusen, C., Gagalick, A., Jagavelu, K., Schuett, H., Tietge, U. J., et al. (2010). Chemokine receptor 7 knockout attenuates atherosclerotic plaque development. Circulation 122, 1621-1628. doi: 10.1161/circulationaha.110. 956730

Ma, X. L., Weyrich, A. S., Lefer, D. J., Buerke, M., Albertine, K. H., Kishimoto, T. K., et al. (1993). Monoclonal antibody to L-selectin attenuates neutrophil accumulation and protects ischemic reperfused cat myocardium. Circulation 88, 649-658. doi: 10.1161/01.cir.88.2.649

Mach, F., Sauty, A., Iarossi, A. S., Sukhova, G. K., Neote, K., Libby, P., et al. (1999). Differential expression of three T lymphocyte-activating CXC chemokines by human atheroma-associated cells. J. Clin. Invest. 104, 1041-1050. doi: 10.1172/ jci6993

Madjid, M., Awan, I., Willerson, J. T., and Casscells, S. W. (2004). Leukocyte count and coronary heart disease: implications for risk assessment. J. Am. Coll. Cardiol. 44, 1945-1956.

Maekawa, Y., Anzai, T., Yoshikawa, T., Asakura, Y., Takahashi, T., Ishikawa, S., et al. (2002). Prognostic significance of peripheral monocytosis after reperfused acute myocardial infarction:a possible role for left ventricular remodeling. J. Am. Coll. Cardiol. 39, 241-246. doi: 10.1016/s0735-1097(01)01721-1

Majmudar, M. D., Keliher, E. J., Heidt, T., Leuschner, F., Truelove, J., Sena, B. F., et al. (2013). Monocyte-directed RNAi targeting CCR2 improves infarct healing in atherosclerosis-prone mice. Circulation 127, 2038-2046. doi: 10. 1161/circulationaha.112.000116

Mamdouh, Z., Chen, X., Pierini, L. M., Maxfield, F. R., and Muller, W. A. (2003). Targeted recycling of PECAM from endothelial surface-connected compartments during diapedesis. Nature 421, 748-753. doi: 10.1038/ nature 01300

Marchini, T., Wolf, D., Michel, N. A., Mauler, M., Dufner, B., Hoppe, N., et al. (2016). Acute exposure to air pollution particulate matter aggravates 
experimental myocardial infarction in mice by potentiating cytokine secretion from lung macrophages. Basic Res. Cardiol. 111:44.

Marchini, T., Zirlik, A., and Wolf, D. (2020). Pathogenic role of air pollution particulate matter in cardiometabolic disease: evidence from mice and humans. Antioxid. Redox Signal. 33, 263-279. doi: 10.1089/ars.2020.8096

Martin-Padura, I., Lostaglio, S., Schneemann, M., Williams, L., Romano, M., Fruscella, P., et al. (1998). Junctional adhesion molecule, a novel member of the immunoglobulin superfamily that distributes at intercellular junctions and modulates monocyte transmigration. J. Cell Biol. 142, 117-127. doi: 10.1083/ jcb.142.1.117

Mauler, M., Herr, N., Schoenichen, C., Witsch, T., Marchini, T., Hardtner, C., et al. (2019). Platelet serotonin aggravates myocardial ischemia/reperfusion injury via neutrophil degranulation. Circulation 139, 918-931. doi: 10.1161/ circulationaha.118.033942

Mayadas, T. N., Johnson, R. C., Rayburn, H., Hynes, R. O., and Wagner, D. D. (1993). Leukocyte rolling and extravasation are severely compromised in $\mathrm{P}$ selectin-deficient mice. Cell 74, 541-554. doi: 10.1016/0092-8674(93)80055-j

McEver, R. P., and Cummings, R. D. (1997). Perspectives series: cell adhesion in vascular biology. Role of PSGL-1 binding to selectins in leukocyte recruitment. J. Clin. Invest. 100, 485-491. doi: 10.1172/jci119556

Meerschaert, J., and Furie, M. B. (1995). The adhesion molecules used by monocytes for migration across endothelium include CD11a/CD18, CD11b/CD18, and VLA-4 on monocytes and ICAM-1, VCAM-1, and other ligands on endothelium. J. Immunol. 154, 4099-4112.

Mendez-Ferrer, S., Battista, M., and Frenette, P. S. (2010). Cooperation of beta(2)and beta(3)-adrenergic receptors in hematopoietic progenitor cell mobilization. Ann. N. Y. Acad. Sci. 1192, 139-144.

Mendez-Ferrer, S., Lucas, D., Battista, M., and Frenette, P. S. (2008). Haematopoietic stem cell release is regulated by circadian oscillations. Nature 452, 442-447. doi: 10.1038/nature06685

Michel, N. A., Zirlik, A., and Wolf, D. (2017). CD40L and its receptors in atherothrombosis-an update. Front. Cardiovasc. Med. 4:40. doi: 10.3389/fcrm. 2017.00040

Minicucci, M. F., Azevedo, P. S., Polegato, B. F., Paiva, S. A., and Zornoff, L. A. (2011). Heart failure after myocardial infarction: clinical implications and treatment. Clin. Cardiol. 34, 410-414. doi: 10.1002/clc.20922

Mollica Poeta, V., Massara, M., Capucetti, A., and Bonecchi, R. (2019). Chemokines and chemokine receptors: new targets for cancer immunotherapy. Front. Immunol. 10:379. doi: 10.3389/fimmu.2019.00379

Murphy, A. J., Akhtari, M., Tolani, S., Pagler, T., Bijl, N., Kuo, C. L., et al. (2011). ApoE regulates hematopoietic stem cell proliferation, monocytosis, and monocyte accumulation in atherosclerotic lesions in mice. J. Clin. Invest. 121, 4138-4149. doi: 10.1172/jci57559

Nageh, M. F., Sandberg, E. T., Marotti, K. R., Lin, A. H., Melchior, E. P., Bullard, D. C., et al. (1997). Deficiency of inflammatory cell adhesion molecules protects against atherosclerosis in mice. Arterioscler. Thromb. Vasc. Biol. 17, 1517-1520. doi: 10.1161/01.atv.17.8.1517

Nahrendorf, M. (2018). Myeloid cell contributions to cardiovascular health and disease. Nat. Med. 24, 711-720. doi: 10.1038/s41591-018-0064-0

Nahrendorf, M., Keliher, E., Panizzi, P., Zhang, H., Hembrador, S., Figueiredo, J. L., et al. (2009). 18F-4V for PET-CT imaging of VCAM-1 expression in atherosclerosis. JACC Cardiovasc. Imaging 2, 1213-1222. doi: 10.1016/j.jcmg. 2009.04.016

Nahrendorf, M., Swirski, F. K., Aikawa, E., Stangenberg, L., Wurdinger, T., Figueiredo, J. L., et al. (2007). The healing myocardium sequentially mobilizes two monocyte subsets with divergent and complementary functions. J. Exp. Med. 204, 3037-3047. doi: 10.1084/jem.20070885

Nakashima, Y., Raines, E. W., Plump, A. S., Breslow, J. L., and Ross, R. (1998). Upregulation of VCAM-1 and ICAM-1 at atherosclerosis-prone sites on the endothelium in the ApoE-deficient mouse. Arterioscler. Thromb. Vasc. Biol. 18, 842-851. doi: 10.1161/01.atv.18.5.842

Naruko, T., Ueda, M., Haze, K., van der Wal, A. C., van der Loos, C. M., Itoh, A., et al. (2002). Neutrophil infiltration of culprit lesions in acute coronary syndromes. Circulation 106, 2894-2900. doi: 10.1161/01.cir.0000042674.89 762.20

Noels, H., Weber, C., and Koenen, R. R. (2019). Chemokines as therapeutic targets in cardiovascular disease. Arterioscler. Thromb. Vasc. Biol. 39, 583-592. doi: 10.1161/atvbaha.118.312037
Ohtani, K., Usui, M., Nakano, K., Kohjimoto, Y., Kitajima, S., Hirouchi, Y., et al. (2004). Antimonocyte chemoattractant protein-1 gene therapy reduces experimental in-stent restenosis in hypercholesterolemic rabbits and monkeys. Gene Ther. 11, 1273-1282. doi: 10.1038/sj.gt.3302288

Palazzo, A. J., Jones, S. P., Girod, W. G., Anderson, D. C., Granger, D. N., and Lefer, D. J. (1998). Myocardial ischemia-reperfusion injury in CD18- and ICAM-1-deficient mice. Am. J. Physiol. 275, H2300-H2307.

Panizzi, P., Swirski, F. K., Figueiredo, J. L., Waterman, P., Sosnovik, D. E., Aikawa, E., et al. (2010). Impaired infarct healing in atherosclerotic mice with Ly-6C(hi) monocytosis. J. Am. Coll. Cardiol. 55, 1629-1638. doi: 10.1016/j.jacc.2009. 08.089

Podrez, E. A., Schmitt, D., Hoff, H. F., and Hazen, S. L. (1999). Myeloperoxidasegenerated reactive nitrogen species convert LDL into an atherogenic form in vitro. J. Clin. Invest. 103, 1547-1560. doi: 10.1172/jci5549

Quintar, A., McArdle, S., Wolf, D., Marki, A., Ehinger, E., Vassallo, M., et al. (2017). Endothelial protective monocyte patrolling in large arteries intensified by western diet and atherosclerosis. Circ. Res. 120, 1789-1799. doi: 10.1161/ circresaha.117.310739

Raab-Westphal, S., Marshall, J. F., and Goodman, S. L. (2017). Integrins as therapeutic targets: successes and cancers. Cancers (Basel) 9:110. doi: 10.3390/ cancers 9090110

Rahman, M. S., Murphy, A. J., and Woollard, K. J. (2017). Effects of dyslipidaemia on monocyte production and function in cardiovascular disease. Nat. Rev. Cardiol. 14, 387-400. doi: 10.1038/nrcardio.2017.34

Robbins, C. S., Chudnovskiy, A., Rauch, P. J., Figueiredo, J. L., Iwamoto, Y., Gorbatov, R., et al. (2012). Extramedullary hematopoiesis generates Ly$6 \mathrm{C}$ (high) monocytes that infiltrate atherosclerotic lesions. Circulation 125, 364-374. doi: 10.1161/circulationaha.111.061986

Ross, R. (1999). Atherosclerosis-an inflammatory disease. N. Engl. J. Med. 340, $115-126$.

Rotzius, P., Thams, S., Soehnlein, O., Kenne, E., Tseng, C. N., Bjorkstrom, N. K., et al. (2010). Distinct infiltration of neutrophils in lesion shoulders in ApoE-/mice. Am. J. Pathol. 177, 493-500. doi: 10.2353/ajpath.2010.090480

Sager, H. B., Dutta, P., Dahlman, J. E., Hulsmans, M., Courties, G., Sun, Y., et al. (2016a). RNAi targeting multiple cell adhesion molecules reduces immune cell recruitment and vascular inflammation after myocardial infarction. Sci. Transl. Med. 8:342ra80. doi: 10.1126/scitranslmed.aaf1435

Sager, H. B., Hulsmans, M., Lavine, K. J., Moreira, M. B., Heidt, T., Courties, G., et al. (2016b). Proliferation and recruitment contribute to myocardial macrophage expansion in chronic heart failure. Circ. Res. 119, 853-864. doi: 10.1161/circresaha.116.309001

Saigusa, R., Winkels, H., and Ley, K. (2020). T cell subsets and functions in atherosclerosis. Nat. Rev. Cardiol. 17, 387-401. doi: 10.1038/s41569-0200352-5

Schenkel, A. R., Mamdouh, Z., and Muller, W. A. (2004). Locomotion of monocytes on endothelium is a critical step during extravasation. Nat. Immunol. 5, 393400. doi: 10.1038/ni1051

Sekido, N., Mukaida, N., Harada, A., Nakanishi, I., Watanabe, Y., and Matsushima, K. (1993). Prevention of lung reperfusion injury in rabbits by a monoclonal antibody against interleukin-8. Nature 365, 654-657. doi: 10.1038/365654a0

Sharma, M., Schlegel, M. P., Afonso, M. S., Brown, E. J., Rahman, K., Weinstock, A., et al. (2020). Regulatory T cells license macrophage pro-resolving functions during atherosclerosis regression. Circ. Res. 127, 335-353. doi: 10.1161/ circresaha.119.316461

Shimaoka, M., Xiao, T., Liu, J. H., Yang, Y., Dong, Y., Jun, C. D., et al. (2003). Structures of the alpha L I domain and its complex with ICAM-1 reveal a shapeshifting pathway for integrin regulation. Cell 112, 99-111. doi: 10.1016/s00928674(02)01257-6

Soehnlein, O. (2012). Multiple roles for neutrophils in atherosclerosis. Circ. Res. 110, 875-888. doi: 10.1161/circresaha.111.257535

Soehnlein, O., Drechsler, M., Doring, Y., Lievens, D., Hartwig, H., Kemmerich, K., et al. (2013). Distinct functions of chemokine receptor axes in the atherogenic mobilization and recruitment of classical monocytes. EMBO Mol. Med. 5, 471-481. doi: 10.1002/emmm.201201717

Stahli, B. E., Gebhard, C., Duchatelle, V., Cournoyer, D., Petroni, T., Tanguay, J. F., et al. (2016). Effects of the P-selectin antagonist inclacumab on myocardial damage after percutaneous coronary intervention according to timing of infusion: insights from the SELECT-ACS trial. J. Am. Heart Assoc. 5:e004255. 
Stocker, C. J., Sugars, K. L., Harari, O. A., Landis, R. C., Morley, B. J., and Haskard, D. O. (2000). TNF-alpha, IL-4, and IFN-gamma regulate differential expression of P- and E-selectin expression by porcine aortic endothelial cells. J. Immunol. 164, 3309-3315. doi: 10.4049/jimmunol.164.6.3309

Stone, G. W., Maehara, A., Lansky, A. J., de Bruyne, B., Cristea, E., Mintz, G. S., et al. (2011). A prospective natural-history study of coronary atherosclerosis. N. Engl. J. Med. 364, 226-235.

Swirski, F. K., Libby, P., Aikawa, E., Alcaide, P., Luscinskas, F. W., Weissleder, R., et al. (2007). Ly-6Chi monocytes dominate hypercholesterolemia-associated monocytosis and give rise to macrophages in atheromata. J. Clin. Invest. 117, 195-205. doi: 10.1172/jci29950

Swirski, F. K., Nahrendorf, M., Etzrodt, M., Wildgruber, M., Cortez-Retamozo, V., Panizzi, P., et al. (2009). Identification of splenic reservoir monocytes and their deployment to inflammatory sites. Science 325, 612-616. doi: 10.1126/science. 1175202

Swirski, F. K., Pittet, M. J., Kircher, M. F., Aikawa, E., Jaffer, F. A., Libby, P., et al. (2006). Monocyte accumulation in mouse atherogenesis is progressive and proportional to extent of disease. Proc. Natl. Acad. Sci. U.S.A. 103, 10340-10345. doi: 10.1073/pnas.0604260103

Tacke, F., Alvarez, D., Kaplan, T. J., Jakubzick, C., Spanbroek, R., Llodra, J., et al. (2007). Monocyte subsets differentially employ CCR2, CCR5, and CX3CR1 to accumulate within atherosclerotic plaques. J. Clin. Invest. 117, 185-194. doi: $10.1172 /$ jci28549

Takada, Y., Ye, X., and Simon, S. (2007). The integrins. Genome Biol. 8:215.

Tardif, J. C., Tanguay, J. F., Wright, S. R., Duchatelle, V., Petroni, T., Gregoire, J. C., et al. (2013). Effects of the P-selectin antagonist inclacumab on myocardial damage after percutaneous coronary intervention for non-STsegment elevation myocardial infarction: results of the SELECT-ACS trial. J. Am. Coll. Cardiol. 61, 2048-2055. doi: 10.1016/j.jacc.2013.03.003

Tedgui, A., and Mallat, Z. (2006). Cytokines in atherosclerosis: pathogenic and regulatory pathways. Physiol. Rev. 86, 515-581. doi: 10.1152/physrev.00024. 2005

Tenaglia, A. N., Buda, A. J., Wilkins, R. G., Barron, M. K., Jeffords, P. R., Vo, K., et al. (1997). Levels of expression of P-selectin, E-selectin, and intercellular adhesion molecule- 1 in coronary atherectomy specimens from patients with stable and unstable angina pectoris. Am. J. Cardiol. 79, 742-747. doi: 10.1016/ s0002-9149(96)00861-2

Vafadarnejad, E., Rizzo, G., Krampert, L., Arampatzi, P., Arias-Loza, A. P., Nazzal, Y., et al. (2020). Dynamics of cardiac neutrophil diversity in murine myocardial infarction. Circ. Res. 127, e232-e249.

van Amerongen, M. J., Harmsen, M. C., van Rooijen, N., Petersen, A. H., and van Luyn, M. J. (2007). Macrophage depletion impairs wound healing and increases left ventricular remodeling after myocardial injury in mice. Am. J. Pathol. 170, 818-829. doi: 10.2353/ajpath.2007.060547

van der Laan, A. M., Ter Horst, E. N., Delewi, R., Begieneman, M. P., Krijnen, P. A., Hirsch, A., et al. (2014). Monocyte subset accumulation in the human heart following acute myocardial infarction and the role of the spleen as monocyte reservoir. Eur. Heart J. 35, 376-385. doi: 10.1093/eurheartj/eht331

van Wanrooij, E. J., de Jager, S. C., van Es, T., de Vos, P., Birch, H. L., Owen, D. A., et al. (2008). CXCR3 antagonist NBI-74330 attenuates atherosclerotic plaque formation in LDL receptor-deficient mice. Arterioscler. Thromb. Vasc. Biol. 28, 251-257. doi: 10.1161/atvbaha.107.147827

van Wanrooij, E. J., Happe, H., Hauer, A. D., de Vos, P., Imanishi, T., Fujiwara, H., et al. (2005). HIV entry inhibitor TAK-779 attenuates atherogenesis in lowdensity lipoprotein receptor-deficient mice. Arterioscler. Thromb. Vasc. Biol. 25 , 2642-2647. doi: 10.1161/01.atv.0000192018.90021.c0

Veillard, N. R., Steffens, S., Pelli, G., Lu, B., Kwak, B. R., Gerard, C., et al. (2005). Differential influence of chemokine receptors CCR2 and CXCR3 in development of atherosclerosis in vivo. Circulation 112, 870-878. doi: 10.1161/ circulationaha. 104.520718

Wan, W., Lionakis, M. S., Liu, Q., Roffe, E., and Murphy, P. M. (2013). Genetic deletion of chemokine receptor Ccr7 exacerbates atherogenesis in ApoEdeficient mice. Cardiovasc. Res. 97, 580-588. doi: 10.1093/cvr/cvs349

Wang, Y., Sakuma, M., Chen, Z., Ustinov, V., Shi, C., Croce, K., et al. (2005). Leukocyte engagement of platelet glycoprotein Ibalpha via the integrin Mac1 is critical for the biological response to vascular injury. Circulation 112, 2993-3000. doi: 10.1161/circulationaha.105.571315
Warnatsch, A., Ioannou, M., Wang, Q., and Papayannopoulos, V. (2015). Inflammation. Neutrophil extracellular traps license macrophages for cytokine production in atherosclerosis. Science 349, 316-320. doi: 10.1126/science. aaa8064

Weirather, J., Hofmann, U. D., Beyersdorf, N., Ramos, G. C., Vogel, B., Frey, A., et al. (2014). Foxp3+ CD4+ T cells improve healing after myocardial infarction by modulating monocyte/macrophage differentiation. Circ. Res. 115, 55-67. doi: 10.1161/circresaha.115.303895

Weninger, W., Crowley, M. A., Manjunath, N., and von Andrian, U. H. (2001). Migratory properties of naive, effector, and memory CD8(+) T cells. J. Exp. Med. 194, 953-966. doi: 10.1084/jem.194.7.953

Weyrich, A. S., Ma, X. Y., Lefer, D. J., Albertine, K. H., and Lefer, A. M. (1993). In vivo neutralization of $\mathrm{P}$-selectin protects feline heart and endothelium in myocardial ischemia and reperfusion injury. J. Clin. Invest. 91, 2620-2629. doi: $10.1172 /$ jci116501

Williams, F. M., Kus, M., Tanda, K., and Williams, T. J. (1994). Effect of duration of ischaemia on reduction of myocardial infarct size by inhibition of neutrophil accumulation using an anti-CD18 monoclonal antibody. Br. J. Pharmacol. 111, 1123-1128. doi: 10.1111/j.1476-5381.1994.tb14861.x

Winkels, H., Ehinger, E., Vassallo, M., Buscher, K., Dinh, H., Kobiyama, K., et al. (2018). Atlas of the immune cell repertoire in mouse atherosclerosis defined by single-cell RNA-sequencing and mass cytometry. Circ. Res. 122, 1675-1688. doi: $10.1161 /$ circresaha.117.312513

Winter, C., Silvestre-Roig, C., Ortega-Gomez, A., Lemnitzer, P., Poelman, H., Schumski, A., et al. (2018). Chrono-pharmacological targeting of the CCL2CCR2 axis ameliorates atherosclerosis. Cell Metab. 28, 175-182.e5.

Wolf, D., Anto-Michel, N., Blankenbach, H., Wiedemann, A., Buscher, K., Hohmann, J. D., et al. (2018). A ligand-specific blockade of the integrin Mac1 selectively targets pathologic inflammation while maintaining protective host-defense. Nat. Commun. 9:525.

Wolf, D., Gerhardt, T., Winkels, H., Michel, N. A., Pramod, A. B., Ghosheh, Y., et al. (2020). Pathogenic autoimmunity in atherosclerosis evolves from initially protective apolipoprotein B100-reactive CD4(+) T-regulatory cells. Circulation 142, 1279-1293. doi: 10.1161/circulationaha.119.042863

Wolf, D., Hohmann, J. D., Wiedemann, A., Bledzka, K., Blankenbach, H., Marchini, T., et al. (2011). Binding of CD40L to Mac-1's I-domain involves the EQLKKSKTL motif and mediates leukocyte recruitment and atherosclerosisbut does not affect immunity and thrombosis in mice. Circ. Res. 109, 1269-1279. doi: 10.1161/circresaha.111.247684

Wolf, D., and Ley, K. (2015). Waking up the stem cell niche: how hematopoietic stem cells generate inflammatory monocytes after stroke. Circ. Res. 116, 389392. doi: $10.1161 /$ circresaha. 114.305678

Wolf, D., and Ley, K. (2019). Immunity and inflammation in atherosclerosis. Circ. Res. 124, 315-327. doi: 10.1161/circresaha.118.313591

Wolf, D., Zirlik, A., and Ley, K. (2015). Beyond vascular inflammation-recent advances in understanding atherosclerosis. Cell. Mol. Life Sci. 72, 3853-3869. doi: 10.1007/s00018-015-1971-6

Worbs, T., and Forster, R. (2007). A key role for CCR7 in establishing central and peripheral tolerance. Trends Immunol. 28, 274-280. doi: 10.1016/j.it.2007. 04.002

Wuttge, D. M., Zhou, X., Sheikine, Y., Wagsater, D., Stemme, V., Hedin, U., et al. (2004). CXCL16/SR-PSOX is an interferon-gamma-regulated chemokine and scavenger receptor expressed in atherosclerotic lesions. Arterioscler. Thromb. Vasc. Biol. 24, 750-755. doi: 10.1161/01.atv.0000124102.11 472.36

Yan, X., Anzai, A., Katsumata, Y., Matsuhashi, T., Ito, K., Endo, J., et al. (2013). Temporal dynamics of cardiac immune cell accumulation following acute myocardial infarction. J. Mol. Cell. Cardiol. 62, 24-35. doi: 10.1016/j.yjmcc. 2013.04.023

Yang, Z., Day, Y. J., Toufektsian, M. C., Xu, Y., Ramos, S. I., Marshall, M. A., et al. (2006). Myocardial infarct-sparing effect of adenosine A2A receptor activation is due to its action on CD4+ T lymphocytes. Circulation 114, 2056-2064. doi: 10.1161/circulationaha.106.649244

Yvan-Charvet, L., Pagler, T., Gautier, E. L., Avagyan, S., Siry, R. L., Han, S., et al. (2010). ATP-binding cassette transporters and HDL suppress hematopoietic stem cell proliferation. Science 328, 1689-1693. doi: 10.1126/science.118 9731 
Zernecke, A., Bot, I., Djalali-Talab, Y., Shagdarsuren, E., Bidzhekov, K., Meiler, S., et al. (2008). Protective role of CXC receptor 4/CXC ligand 12 unveils the importance of neutrophils in atherosclerosis. Circ. Res. 102, 209-217. doi: 10.1161/circresaha.107.160697

Zernecke, A., and Weber, C. (2014). Chemokines in atherosclerosis: proceedings resumed. Arterioscler. Thromb. Vasc. Biol. 34, 742-750. doi: 10.1161/atvbaha. 113.301655

Zernecke, A., Winkels, H., Cochain, C., Williams, J. W., Wolf, D., Soehnlein, O., et al. (2020). Meta-Analysis of leukocyte diversity in atherosclerotic mouse aortas. Circ. Res. 127, 402-426. doi: 10.1161/circresaha.120.316903

Zhang, S., Wan, Z., Zhang, Y., Fan, Y., Gu, W., Li, F., et al. (2015). Neutrophil count improves the GRACE risk score prediction of clinical outcomes in patients with ST-elevation myocardial infarction. Atherosclerosis 241, 723-728. doi: 10.1016/j.atherosclerosis.2015.06.035

Zirlik, A., Maier, C., Gerdes, N., MacFarlane, L., Soosairajah, J., Bavendiek, U., et al. (2007). CD40 ligand mediates inflammation independently of CD40 by interaction with Mac-1. Circulation 115, 1571-1580. doi: 10.1161/ circulationaha.106.683201
Zouggari, Y., Ait-Oufella, H., Bonnin, P., Simon, T., Sage, A. P., Guerin, C., et al. (2013). B lymphocytes trigger monocyte mobilization and impair heart function after acute myocardial infarction. Nat. Med. 19, 1273-1280. doi: 10.1038/nm. 3284

Conflict of Interest: DW holds patents on the inhibition of the leukocyte integrin Mac-1 by peptide mimetics and antibodies (EP 2444101 A1/EP 3260133 A1).

The remaining authors declare that the research was conducted in the absence of any commercial or financial relationships that could be construed as a potential conflict of interest.

Copyright (๑) 2021 Marchini, Mitre and Wolf. This is an open-access article distributed under the terms of the Creative Commons Attribution License (CC BY). The use, distribution or reproduction in other forums is permitted, provided the original author(s) and the copyright owner(s) are credited and that the original publication in this journal is cited, in accordance with accepted academic practice. No use, distribution or reproduction is permitted which does not comply with these terms. 